\title{
Volatile fatty acids in the digestive tract of the fowl
}

\author{
By E. F. ANNISON, K. J. HILL AND R. KENWORTHY \\ Unilever Research Laboratory, Colworth House, Sharnbrook, Bedford
}

(Received 30 August 1967-Accepted I8 December 1967)

\begin{abstract}
1. Examination of the digesta from all regions of the avian digestive tract showed that volatile fatty acids (VFAs) were present in greatest concentration in the caeca and that they comprised mainly acetic, propionic and butyric acids.

2. All droppings contained VFAs but they were present in highest concentration in those of caecal origin. Caecectomy was followed by a marked reduction in the total output of VFAs.

3. Birds $14-20$ weeks of age had similar concentrations of VFAs along the tract and similar numbers and distribution of micro-organisms.

4. Portal blood contained all the VFAs found in the digestive tract whilst peripheral blood contained only acetic and formic acids.

5. The almost complete absence of VFAs from the tract contents of germ-free birds showed that the VFAs normally present in the tract were of microbial origin.

6. The presence of similar levels of acetate in the peripheral blood of conventional and germfree birds indicated that circulating acetate was mainly of endogenous and not microbial origin.

7. The significance of VFAs as an energy source is discussed.
\end{abstract}

The role of the caeca in the digestive processes of the domestic fowl is generally considered to be of little importance, largely because removal of the caeca has no apparent effect on growth rate and performance. There is, however, some evidence that caecectomy leads to much lower digestibility coefficients for the crude fibre of wheat and maize; Halnan (1949) and more recently Thornburn \& Willcox (1965) have demonstrated that caecectomy of young cockerels is followed by a reduction in droppings dry matter and overall food digestibility. Cellulose digestibility in a given bird was lowered but the effect was not always evident between one bird and another, a finding explained on the basis of differences in the caecal flora of individual birds.

The fermentative abilities of the caecal flora have, in fact, been recognized for many years, although surprisingly little is known about their metabolic activities or of the fate of the end-products. Beattie \& Shrimpton (1958) were able to show that the microbial activities in the caeca were essentially fermentative. The occurrence of volatile fatty acids (VFAs) was demonstrated (Shrimpton, 1963) and it was subsequently reported that strains of bacteroides in the caeca fermented glucose with the production of acetic and propionic acids (Shrimpton \& Stevens, 1965). We have confirmed and extended these observations on caecal VFAs and demonstrated their absorption into the portal system as a preliminary to an evaluation of their significance as an energy source to the fowl.

\section{EXPERIMENTAL}

Eighteen in-lay New Hampshire $\times$ Light Sussex hens and ten Light Sussex cocks, 24 weeks of age, were used during this investigation. They were housed in individual cages and received a standard commercial diet ad lib. (Complete Lay-feed pellets or 
crumbles; BOCM Ltd, London). Water was freely available at all times. In addition seven Light Hybrids (Thornber 606) maintained on deep litter and fed on a standard prelay ration (BOCM Ltd, London) were used for bacteriological studies on the caecal flora in relation to the VFAs produced.

\section{Germ-free birds}

The procedures for deriving germ-free birds were based on those described by Reyniers, Trexler, Ervin, Wagner, Luckey \& Gordon (1949) and Forbes \& Park (1959). Fertile eggs which had been incubated for 18 days were carefully washed in $3 \%(\mathrm{v} / \mathrm{v})$ Marinol ' $D$ ' (based on benzalkonium chloride) (Reddish Chemical Co. Ltd, Cheadle, Cheshire) for 2 min before being immersed in a $2 \%$ solution of mercuric chloride. After $8 \mathrm{~min}$ immersion in mercuric chloride they were rinsed in a fresh solution of Marinol ' $D$ ' and then passed through a germicidal trap into a hatching unit previously sterilized by spraying with a $2 \%$ solution of peracetic acid. All washing and sterilizing solutions were maintained at a temperature of $37.5^{\circ}$.

The diet was identical to that supplied to conventional birds (Babychick Mash, Intensive Growers Mash; BOCM Ltd, London) but was sterilized by $\gamma$-irradiation at $5 \mathrm{Mrad}$.

\section{Operative techniques}

Caecectomy was performed on two 6-month-old cocks under closed-circuit cyclopropane oxygen anaesthesia (Hill \& Noakes, 1964). A left laparotomy was made to expose the junction of the caeca with the colon and, after transection close to the colon and closure of the stump attached to the colon with inversion sutures, each caecum was dissected away from its mesentery. The larger vessels in the mesentery were tied off and after removal of the caeca the abdominal wall was closed in three separate layers. Recovery was uneventful. Regeneration of the caeca had not occurred 8 months later when the birds were examined post mortem.

One 9-month-old hen was colostomized for the separate collection of urine and faeces. The colon was separated from the cloaca and after closure of the cloaca with an infolding suture a Perspex cannula was inserted into the end of the colon. This cannula was then brought out through a stab wound in the body wall and the original incision closed.

\section{Other experimental procedures}

Contents from the various regions of the digestive tract were obtained from birds which were killed with an intravenous injection of sodium pentobarbitone (Nembutal (Veterinary); Abbott Laboratories Ltd). The viscera were exposed immediately after death and ligatures placed around the digestive tract at appropriate points to minimize the movement of material from one region to another. The different segments of the tract were then removed and the entire contents mixed and placed in polythene containers either for immediate analysis or for storage at $-10^{\circ}$.

Peripheral blood samples were removed from a wing vein or by cardiac puncture; portal blood samples were obtained directly from the portal vein of the anaesthetized bird. Heparin (Pularin; Evans Medical Ltd) was used as an anti-coagulant. 


\section{Analytical methods}

Total levels of VFAs in blood were measured as described earlier (Annison, I954), and the isolated VFAs examined by gas-liquid chromatography (GLC) using the procedure of James \& Martin (1952).

Blood acetate concentrations were subsequently checked by an improved GLC technique and an internal standard. Sodium propionate $(\mathrm{I} 20 \mu \mathrm{g})$ was added to blood $(2 \mathrm{ml})$ before deproteinization and steam distillation. The neutralized distillate was evaporated to dryness, dissolved in $0.2 \mathrm{ml} 5 \%(\mathrm{w} / \mathrm{v}) \mathrm{H}_{3} \mathrm{PO}_{4}$, and $10 \mu \mathrm{l}$ of the solution were examined by GLC (W. G. Pye and Co. Ltd, Model 104). The stationary phase was $20 \%$ neo-pentyl glycol adipate on 60-70 mesh size $\mathrm{H}_{3} \mathrm{PO}_{4}$-washed celite (W. G. Pye and Co. Ltd), and the operating temperature $125^{\circ}$. A flame-ionization detector was used. The concentration of acetate was calculated from the relative areas of the acetate and propionate peaks, and from the known detector response factors.

Gut contents were homogenized with water (ro vol/g contents) and deproteinized with $25 \%(\mathrm{w} / \mathrm{v}) m$-phosphoric acid; the filtrate was neutralized and concentrated in vacuo at $35-40^{\circ}$ before steam distillation at $\mathrm{pH} 4 \cdot 0$. Two roo $\mathrm{ml}$ portions of distillate were collected and titrated with $\mathrm{CO}_{2}$-free $0 \cdot 0 \mathrm{r} \mathrm{N}-\mathrm{NaOH}$ under $\mathrm{CO}_{2}$-free conditions with phenolphthalein as indicator. When the titration values on the second distillate (blank) exceeded $0.2 \mathrm{ml}$ the first distillate was neutralized, concentrated and redistilled at $\mathrm{pH} 4 \cdot 0$. The VFAs obtained by concentrating the first distillate (after titration) were examined by GLC as described above.

\section{Bacteriological techniques}

Ligatures were applied to the crop, small intestine, caeca and colon immediately after death. The contents of each ligatured portion were removed aseptically and about I $\mathrm{g}$ was expressed into a weighed, sterile sample bottle. The quantity of intestinal material taken was weighed by difference, and decimal dilutions were prepared in reinforced clostridial medium (RCM) broth (Hirsch \& Grinsted, 1954). Surface plate counts were carried out by the technique of Miles \& Misra (1938) on the following media: (I) nutrient agar $+5 \%$ washed ovine red cells; (2) nutrient agar $+5 \%$ washed ovine red cells + penicillin ( 2 units $/ \mathrm{ml}$ ); (3) MacConkey's bile salt neutral red lactose agar; (4) RCM agar $+5 \%$ citrated ovine blood; (5) RCM agar $+5 \%$ citrated ovine blood + neomycin sulphate (7o $\mu \mathrm{g} / \mathrm{ml}) ;(6)$ Rogosa agar (Rogosa, Mitchell \& Wiseman, I95 I); (7) malt agar + penicillin (20 units $/ \mathrm{ml}$ ) and streptomycin (40 units $/ \mathrm{ml}$ ).

Plates prepared from (I), (2) and (3) were incubated aerobically at $37^{\circ}$ for $24 \mathrm{~h}$; those prepared from (4), (5) and (6) were incubated anaerobically for $4^{8} \mathrm{~h}$ at $37^{\circ}$. The malt plates were incubated aerobically at $25^{\circ}$ for 5 days.

Using colonial and cell morphology and reaction to Gram's stain, the broad classification scheme described by Kenworthy \& Crabb (1963) was applied. Later, the predominating bacteria were purified and freeze-dried, and more detailed identification was carried out.

All bacterial counts are expressed as the logarithm of the viable count to the base Io. 
RESULTS

Distribution of volatile fatty acids in the digesta from different regions of the digestive tract

The total VFA contents of digesta from different regions of the tract of three hens are shown in Table 1 . With one exception, no. 132, the caecal contents contained a much greater concentration of VFAs than material from other parts of the tract. In this bird the colonic contents resembled caecal material and, in view of its high VFA

Table I. Concentration and total content of volatile fatty acids in the different regions of the digestive tract and in the entire tract of three hens receiving a diet of Complete Layfeed pellets

\begin{tabular}{|c|c|c|c|c|c|c|}
\hline \multirow[b]{2}{*}{ Regi } & \multicolumn{2}{|c|}{ Hen no. 132} & \multicolumn{2}{|c|}{ Hen no. 2} & \multicolumn{2}{|c|}{ Hen no. 4} \\
\hline & $\begin{array}{c}\text { VFA } \\
\text { concen- } \\
\text { tration } \\
\text { (m-moles/ } \\
\mathrm{kg})\end{array}$ & $\begin{array}{c}\text { VFA } \\
\text { content } \\
(\mathrm{m} \text {-moles })\end{array}$ & $\begin{array}{c}\text { VFA } \\
\text { concen- } \\
\text { tration } \\
\text { (m-moles/ } \\
\text { kg) }\end{array}$ & $\begin{array}{c}\text { VFA } \\
\text { content } \\
(\mathrm{m} \text {-moles })\end{array}$ & $\begin{array}{c}\text { VFA } \\
\text { concen- } \\
\text { tration } \\
\text { (m-moles/ } \\
\text { kg) }\end{array}$ & $\begin{array}{c}\text { VFA } \\
\text { content } \\
\text { (m-moles) }\end{array}$ \\
\hline $\begin{array}{l}\text { Proventriculus } \\
\text { and gizzard }\end{array}$ & 6 & 0.16 & 5 & 0.06 & 4 & 0.06 \\
\hline Duodenum & I I & 0.07 & 8 & 0.03 & 6 & 0.04 \\
\hline Small intestine & 14 & 0.34 & 10 & 0.21 & 6 & 0.13 \\
\hline Caeca & ror & $0 \cdot 32$ & 106 & 0.46 & I 15 & 0.74 \\
\hline Colon & 132 & 0.25 & 16 & 0.05 & 7 & 0.04 \\
\hline Total & & $I \cdot I 4$ & & $0.8 I$ & & $I \cdot O I$ \\
\hline
\end{tabular}

Table 2. Individual volatile fatty acids in caecal contents expressed as percentages of the total from ten hens receiving Complete Lay-feed pellets

$\begin{array}{ccccccc}\text { Hen no. } & \text { Acetic } & \text { Propionic } & \text { iso-Butyric } & n \text {-Butyric } & \begin{array}{c}\text { iso-Valeric and } \\ \text { 2-methyl butyric }\end{array} & n \text {-Valeric } \\ 26 & 56 & 22 & 2 & 12 & 3 & 3 \\ 3 & 52 & 38 & 0 & 9 & 0.5 & 0.5 \\ 39 & 63 & 26 & 0 & 8 & 1 & 2 \\ 4 \text { I } & 68 & 24 & 0 & 5 & 0 & 3 \\ 53 & 70 & 19 & 0 & \text { I I } & 0 & 1 \\ 21 & 58 & 31 & 0 & 9 & 1 & 3 \\ 22 & 45 & 35 & 3 & 1 \text { I } & 3 & 4 \\ 23 & 47 & 32 & 2 & \text { I I } & 4 & 2 \\ 24 & 50 & 29 & 3 & 14 & 4 & 2 \\ 25 & 50 & 32 & 3 & 9 & & 2\end{array}$

concentration, it seemed probable that this represented material which had been discharged from the caeca as the bird was killed. An estimate of the total amount of VFA and its distribution along the tract is also shown in Table $\mathrm{r}$.

Further examination of the caecal contents from twelve hens of varying age and which were receiving several different diets was made as the opportunity arose, and VFA concentrations of IOI $-242 \mathrm{~m}$-moles $/ \mathrm{kg}$ were found. 
Table 3. Concentration and output of volatile fatty acids in individual droppings collected over $a{ }_{9} h$ period from a cock receiving Complete Lay-feed pellets

\begin{tabular}{|c|c|c|c|}
\hline Dropping no. & $W_{t}(g)$ & $\begin{array}{c}\text { VFA } \\
(\mathrm{m}-\mathrm{moles} / \mathrm{kg})\end{array}$ & $\begin{array}{l}\text { VFA output } \\
\text { (m-moles) }\end{array}$ \\
\hline I & $3 \cdot 6$ & 40 & 0.14 \\
\hline 2 & $4 \cdot 6$ & 86 & 0.39 \\
\hline 3 & $5 \cdot 3$ & 36 & 0.19 \\
\hline 4 & 1.6 & $3^{\circ}$ & 0.05 \\
\hline 5 & $5 \cdot 7$ & 42 & 0.24 \\
\hline 6 & $5 \cdot 5$ & 33 & 0.18 \\
\hline 7 & 5.6 & 44 & 0.25 \\
\hline 8 & $8 \cdot 5$ & 37 & 0.31 \\
\hline 9 & II. 2 & 58 & 0.65 \\
\hline Io & 10.4 & 76 & 0.79 \\
\hline Total & $62 \cdot 0$ & - & $3 \cdot 19$ \\
\hline
\end{tabular}

Composition of the VFAs present in the caecal contents

Partition analysis was carried out on the caecal contents of ten hens. The results are shown in Table 2 and it will be seen that in every instance acetic acid was present in greatest proportion. Propionic and $n$-butyric acids were next in order of magnitude whilst only trace amounts of the other acids were present. The relative proportion of acetic to propionic acid varied slightly in different birds on the same diet and probably represented variations in the type of fermentation or in the rate of absorption of the different acids.

\section{Amount and composition of VFAs in the droppings}

Examination of individual droppings from a number of cocks revealed the presence of VFAs in concentrations varying from 26 to $86 \mathrm{~m}$-moles $/ \mathrm{kg}$. Caecal droppings had a much higher concentration of VFA.

Table 3 shows the total VFA concentration present in each individual dropping collected from a cock throughout a $9 \mathrm{~h}$ period whilst the bird was in its normal surroundings with food available ad lib. The total output of VFA in each dropping and the output over the entire period are also shown.

VFAs were present in all the droppings and those which contained obvious caecal material had concentrations approaching those found in caecal digesta. All the droppings had VFA concentrations much higher than those found in the contents of the tract, apart from those of the caeca.

Partition analysis on the VFAs obtained from the droppings showed a distribution similar to that in caecal contents.

Examination of the droppings from laying hens also revealed the presence of VFAs but their concentration tended to be lower and was related to the greater moisture content of these droppings.

\section{Site of production of the VFAs}

A further attempt to determine the relative importance of different regions of the tract in so far as VFA production was concerned was made by comparing the VFA concentration in the droppings of normal cocks and two caecectomized cocks receiving 
identical diets. Individual droppings were collected as they were evacuated on thirteen different occasions over an 8-month period and the mean concentration in the droppings from the caecectomized cocks was $36.8 \mathrm{~m}$-moles $/ \mathrm{kg}$ whilst that in the droppings from two normal cocks was $91.8 \mathrm{~m}$-moles $/ \mathrm{kg}$. This indicated that the caeca were the major sites of VFA production although there were obviously other sources, as analysis of material from other parts of the tract had already shown.

The possibility that urine was a source of VFA was examined by analysing urine from a colostomized hen. Three separate samples of faeces from this bird contained respectively $175^{\circ}$ (caecal), 90.0 and $71.0 \mathrm{~m}$-moles $\mathrm{VFA} / \mathrm{kg}$, and the urine samples, collected over the same periods as the faeces, $2 \cdot 7,4 \cdot 5$ and $5.6 \mathrm{~m}$-moles $/ 1$.

\section{Fermentative activity in the digestive tract of birds of different ages}

Seven growing birds (Thornber 606), aged I 4-20 weeks, were used to study possible changes in the extent and nature of VFA production along the tract with age. The concentrations of VFAs in comparable regions of the tract were similar in all birds and, as in adults, the highest concentration was found in the caeca (Table 4).

Partition analysis revealed a pattern of VFA distribution similar to that in the adult bird, acetic acid being the major component.

Table 4. Total volatile fatty acid concentration $(\mathrm{m}-\mathrm{moles} / \mathrm{kg})$ in digesta from different regions of the digestive tract of fowl of different ages receiving a prelay ration

\begin{tabular}{|c|c|c|c|c|c|}
\hline Fowl no. & Age (weeks) & Crop & Jejunum & Caeca & Colon \\
\hline $\mathrm{BB}_{17}$ & 14 & I3 & II & 65 & 13 \\
\hline $\mathrm{BB} 2 \mathrm{O}^{\circ}$ & 15 & 16 & 8 & 60 & 16 \\
\hline $\mathrm{BB} 22$ & 16 & $2 I$ & 14 & 88 & - \\
\hline $\mathrm{BB} 24$ & 17 & I I & IO & 一 & 13 \\
\hline $\mathrm{BB} 29$ & 18 & I4 & 9 & - & 9 \\
\hline $\mathrm{BB}_{3} \mathrm{r}$ & I9 & 10 & 8 & - & 6 \\
\hline $\mathrm{BB} 23$ & 20 & 8 & 5 & - & 8 \\
\hline
\end{tabular}

\section{Absorption of VFAs}

Four in-lay hens were anaesthetized and samples of portal blood were removed for analysis. The birds were then killed and the caecal contents collected for determination of VFAs. All the VFAs present in the caecal contents were found in portal blood and, in addition, formic acid (Table 5). Peripheral venous blood was examined from a number of hens and was found to contain acetic and formic acids only.

\section{VFAs in the germ-free bird}

Conclusive evidence that microbial fermentation in the caeca is the major source of VFA formation was obtained by the use of germ-free birds. In these preparations the caecal contents were sterile and contained only negligible amounts of VFAs, presumably of dietary origin. In control birds of the same age maintained on the same diet there were appreciable concentrations of VFAs in the caecal contents. The VFA concentration in the peripheral venous blood of the germ-free birds was, however, similar to that in the blood of conventional birds and consisted solely of acetic and formic acids (Table 6). 


\section{Bacteriology of the digestive tract}

The results for the five major microbial groups identified (Escherichia coli, lactobacilli, Bacteroides spp., Bacillus spp. and Gram-positive cocci) are summarized in Table 7 , which shows minimal and maximal numbers in the four intestinal regions.

Other organisms occasionally isolated were yeasts, actinomycetes, Proteus spp., clostridia, streptobacilli and Gram-negative cocci.

Table 5. Individual volatile fatty acids, expressed as percentages of the total, in caecal contents and portal blood from four hens receiving Complete Lay-feed pellets

\begin{tabular}{|c|c|c|c|c|c|c|c|c|}
\hline Hen no. & Material & Acetic & Propionic & $\begin{array}{l}\text { iso- } \\
\text { Butyric }\end{array}$ & n-Butyric & $\begin{array}{l}\text { iso-Valeric and } \\
\text { 2-methyl butyric }\end{array}$ & $n$-Valeric & Formic \\
\hline \multirow[t]{2}{*}{3} & $\begin{array}{l}\text { Caecal } \\
\text { contents }\end{array}$ & 52 & $3^{8}$ & 0 & 9 & I & I & 0 \\
\hline & $\begin{array}{l}\text { Portal } \\
\text { blood }\end{array}$ & 69 & I3 & 0 & 2 & I & I & 14 \\
\hline \multirow[t]{2}{*}{39} & $\begin{array}{l}\text { Caecal } \\
\text { contents }\end{array}$ & 68 & 24 & 0 & 5 & $\circ$ & 3 & 。 \\
\hline & $\begin{array}{l}\text { Portal } \\
\text { blood }\end{array}$ & 62 & I 5 & 0 & 5 & $\mathbf{I}$ & I & 16 \\
\hline \multirow[t]{2}{*}{$4 I$} & $\begin{array}{l}\text { Caecal } \\
\text { contents }\end{array}$ & 70 & 19 & $\circ$ & I I & 0 & $\circ$ & $\circ$ \\
\hline & $\begin{array}{c}\text { Portal } \\
\text { blood }\end{array}$ & 57 & 15 & $\circ$ & 7 & $\mathbf{I}$ & $\circ$ & 20 \\
\hline \multirow[t]{2}{*}{53} & $\begin{array}{l}\text { Caecal } \\
\text { contents }\end{array}$ & 58 & $3 \mathrm{I}$ & $\circ$ & 9 & I & I & $\circ$ \\
\hline & $\begin{array}{c}\text { Portal } \\
\text { blood }\end{array}$ & 63 & 17 & $\mathbf{I}$ & 4 & 0 & $\circ$ & I6 \\
\hline
\end{tabular}

Table 6. Total concentration of volatile fatty acids in caecal contents ( $m$-moles $/ \mathrm{kg})$ and peripheral blood ( $m$-moles $/ \mathrm{l}$.) of four conventional and four germ-free chickens at different ages receiving Baby Chick Mash (to 6 weeks) and Growers Mash (to I6 weeks)

\begin{tabular}{lccc}
\multicolumn{1}{c}{ Material } & Age (weeks) & Conventional & Germ-free \\
Caecal contents & $\mathbf{2}$ & 10.0 & 0.3 \\
Peripheral blood & 2 & 0.3 & 0.2 \\
Caecal contents & 5 & 70.0 & 3.5 \\
Peripheral blood & 5 & 0.8 & 1.0 \\
Caecal contents & 5 & 70.0 & 3.5 \\
Peripheral blood & 5 & 0.8 & 0.7 \\
Caecal contents & 16 & 127.8 & 7.2 \\
Peripheral blood & 16 & 0.7 & 0.7
\end{tabular}

It was found that, whereas the count of individual species of organisms might vary between the different intestinal regions sampled in any one bird, there was no difference in the counts obtained from the same region of different birds, irrespective of age.

A study of the frequency distribution of the various microbial groups indicated that the floras of the crop, small intestine and colon were qualitatively similar. The flora of the caeca differed in that Bacillus spp. and Gram-positive cocci were less common whereas Bacteroides spp. were far more abundant. 
Table 7. Microbial flora of the intestinal tract of fowl (14-20 weeks old) receiving a prelay ration: range of viable counts $\left(\log _{10}\right) / g$ intestinal contents

$\begin{array}{lccccc}\text { Intestinal region } & \begin{array}{c}\text { Escherichia } \\ \text { coli }\end{array} & \text { Lactobacilli } & \begin{array}{c}\text { Bacteroides } \\ \text { spp. }\end{array} & \text { Bacillus spp. } & \text { Gram +ve } \\ \text { cocci }\end{array}$

\section{DISCUSSION}

Evidence that the gut flora, particularly the caecal flora, is important in the nutrition of the bird has been presented by a number of workers with particular reference to vitamin synthesis in the gut (see Coates, I962; Coates \& Jayne-Williams, I966). Other products of bacterial metabolism have not been investigated extensively although it has long been recognized that the breakdown of crude fibre is a fermentative process which takes place in the caeca and possibly the crop. The end-products of this process and of the fermentation of simpler carbohydrates have not been completely identified (Thornburn \& Willcox, 1965) although the gas mixture produced during fermentation has been shown to be similar in composition to that found in the ruminant forestomach (Beattie \& Shrimpton, I958), where large amounts of VFAs are produced.

The results presented here show that VFAs are the major end-products of fermentation in the digestive tract of the fowl and that the caeca are the main sites of their formation. As in the tract of other species, e.g. the rumen and the pig caecum, acetic acid is produced in greatest quantity, with lesser amounts of propionic and butyric acid and trace amounts of other acids, the pattern being characteristic of fermentative activity under strict anaerobiosis.

The type and extent of fermentation depends on the microbial population and the nature and amount of substrate which enters the caeca. The chick embryo is normally sterile and it is only after hatching that organisms are detectable in the digestive tract. Within a few hours of taking food and water there is a rapid establishment of organisms and Lev \& Briggs (1956) have shown that the flora present at 2 days of age is very similar to that of the month-old fowl. The evidence presented here shows that there was little difference in the total amount of VFAs and in the individual acids produced in the caeca of fowl aged I4-20 weeks. Parallel bacteriological studies showed that there was no difference in the numbers of organisms from the same region of the tract of birds of different ages.

The manner in which the caecal tubes fill and empty is not fully understood, although the belief that retroperistalsis of the colon plays a part (Browne, I922) has recently been confirmed by radiographic studies on the conscious fowl (Akester, Anderson, Hill \& Osbaldiston, 1967 ). There is no information on the composition of the substrate which enters the caeca, but it is likely to be a mixture of starch, fibre and simple carbohydrate which has escaped digestion in the upper part of the tract, together with a variable amount of urine. Different starches pass through the tract at different rates and it is probable that the extent of their enzymic breakdown will 
vary (Masson, 1954). Differences in the amount of VFAs produced and in the proportion of individual acids may therefore relate to the relative proportions of different starches present in the diet.

No attempt was made in the present work to relate different diets to the amount and proportions of VFAs found in the caeca or to establish a time course for the rate of fermentation. The fact that relatively high concentrations of VFAs were found in the caeca irrespective of when the birds were killed and that the droppings invariably contained VFAs suggests that caecal filling and emptying may be a continuous process resulting in a fairly uniform rate of fermentation. The well-defined caecal dropping which consists entirely of caecal material occurs infrequently and may represent the need for the intermittent removal of accumulated bacterial bodies. Roseler (1929) has, in fact, shown that caecal droppings have a higher proportion of total nitrogen in the form of protein than ordinary droppings and this may well represent bacterial protein.

Although caecectomy effectively reduced the level of VFAs found in the droppings, the VFAs were not completely eliminated and it seems probable that other regions of the tract may have assumed, to some extent, the role of the caeca. A similar situation has been suggested in relation to vitamin synthesis by the intestinal flora (Coates, 1962).

The presence of a spectrum of VFAs in portal blood similar to that in caecal contents indicated that absorption of fermentation products had taken place and that the liver was therefore receiving a continuous supply of these acids. The absence of all the acids, except acetic and formic, from peripheral blood was evidence that they were taken up and metabolized by the liver, whilst the presence of an appreciable level of acetate in the peripheral blood indicated either that the liver was unable to handle all the acetate derived from the digestive tract or that there was a significant endogenous contribution to the level of circulating acetate. All metabolic processes proceeding via acetyl $\mathrm{CoA}$ are potential contributors to endogenous acetate formation, and that these processes were indeed the major source of blood acetate was shown unequivocally by the fact that blood acetate level of germ-free birds was similar to that of conventional ones.

It is difficult to obtain values for the rate of production of VFAs in the tract. The total amount present in the entire tract ranged approximately from 0.5 to $\mathrm{I} \cdot \mathrm{O} \mathrm{m}$-mole and, as the concentration in portal blood varied from 0.5 to $\mathrm{I} \cdot 0 \mathrm{~m}-\mathrm{mole} / \mathrm{l}$, it is obvious that production and absorption were taking place continuously. On the assumption that portal blood flow is $30 \%$ of cardiac output (Fegler \& Hill, 1958) and that the latter value in the fowl is about $300 \mathrm{ml} / \mathrm{min}$ (Sturkie, 1965) I 1 . of blood will enter the liver from the portal vein every Io min, i.e. $3^{\circ} \circ \mathrm{m}$-moles VFA/h or $7^{2} \mathrm{~m}$-moles VFA/ $24 \mathrm{~h}$ or $4.3 \mathrm{~g} / 24 \mathrm{~h}$.

The role of acetate in the overall metabolism of the fowl has been studied by isotope dilution techniques which showed that total acetate entry rates were about I6 and $9 \mathrm{~g} / 24 \mathrm{~h}$ respectively in fed and starved $(48 \mathrm{~h})$ birds, acetate accounting for II and $6 \%$, respectively, of total energy production (Annison, Shrimpton \& West, 1967). These entry rates suggest that acetate absorbed from the alimentary tract accounts for only about $25 \%$ of total entry in the fed bird, thus emphasizing the greater importance 
of endogenous acetate production. It is possible, however, that the extent of VFA production in the caeca may be modified under different dietary regimes or by alterations in the caecal flora. Exogenously derived acetate may then become of greater significance as an energy source.

We are greatly indebted to Miss Sally Beastall, BSc, who carried out the bacteriological investigations whilst an Industrial Training Student in these laboratories.

\section{REFERENCES}

Akester, A. R., Anderson, R. S., Hill, K. J. \& Osbaldiston, G. W. (1967). Br. Poult. Sci. 8, 209.

Annison, E. F. (1954). Biochem. F. 58, 670.

Annison, E. F., Shrimpton, D. H. \& West, C. E. (1967). European Association of Animal Production, IVth Energy Symposium, Warsaw. (In the Press.)

Beattie, J. \& Shrimpton, D. H. (1958). Q. Yl exp. Physiol. 43, 399.

Browne, T. G. (1922). F. comp. Path. Ther. 35, 12.

Coates, M. E. (1962). In Nutrition of Pigs and Poultry, p. 161. [J. T. Morgan and D. Lewis, editors.] London: Butterworths.

Coates, M. E. \& Jayne-Williams, J. D. (1966). In Physiology of the Domestic Fowl, p. I83. [C. HortonSmith and E. C. Amoroso, editors.] Edinburgh and London: Oliver and Boyd.

Fegler, G. \& Hill, K. J. (1958). Q. Fl exp. Physiol. 43, I89.

Forbes, M. \& Park, J. T. (1959). F. Nutr. 67, 69.

Halnan, E. T. (1949). Br. F. Nutr. 3, 245.

Hill, K. J. \& Noakes, D. E. (1964). In Small Animal Anaesthesia. [O. Graham-Jones, editor.] London: Pergamon Press.

Hirsch, A. \& Grinsted, E. (1954). F. Dairy Res. 21, ror.

James, A. T. \& Martin, A. J. P. (1952). Biochem. F. 5o, 679.

Kenworthy, R. \& Crabb, W. E. (1963). F. comp. Path. Ther. 73, 215.

Lev, M. \& Briggs, C. A. E. (x956). F. appl. Bact. x9, 224.

Masson, M. J. (1954). Wld's Poult. Congr. x, Edinburgh, p. 105

Miles, A. A. \& Misra, S. S. (1938). F. Hyg., Camb. 38, 232.

Reyniers, J. A., Trexler, P. C., Ervin, R. F., Wagner, M., Luckey, T. D. \& Gordon, H. A. (1949). Lobund Rep. no. 2.

Rogosa, M., Mitchell, J. A. \& Wiseman, R. F. (1951). f. Bact. 62, I32.

Roseler, M. (1929). Quoted in Biology and Comparative Physiology of Birds (1960). [A. J. Marshall, editor.] Vol. r. New York and London: Academic Press Inc.

Shrimpton, D. H. (1963). Y. appl. Bact. 26, i.

Shrimpton, D. H. \& Stevens, B. J. H. (1965). F. gen. Microbiol. 4r, v.

Sturkie, P. D. (1965). Avian Physiology, and ed. London: Baillière, Tindall and Cassell.

Thornburn, C. C. \& Willcox, J. S. (1965). Br. Poult. Sci. 6, 23. 